TO MAEGA | Jurnal Pengabdian Masyarakat

P-ISSN: 2622-6332 \& E-ISSN: 2622-6340

TOMAEGA Volume 2 Nomor 1, Februari 2019, hlm : 25 - 29

\title{
PEMBERDAYAAN MASYARAKAT MELALUI WIRAUSAHA KRIPIK IKAN TERI DI KAMPUNG NELAYAN KOTA PALOPO
}

\author{
Sukriming Sapareng ${ }^{1}$ dan Rosnina ${ }^{2}$ \\ ${ }^{1}$ Email: miming.mlgke@gmail.com \\ Fakultas Pertanian Universitas Andi Djemma \\ ${ }^{2}$ Email: ninabonebone@yahoo.com \\ Fakultas Pertanian Universitas Andi Djemma
}

\begin{abstract}
Abstrak. Salah satu bentuk usaha yang memungkinkan dilakukan oleh ibu rumah tangga adalah dengan berwirausaha membuat kerupuk. Produk olahan makanan berbahan ikan teri dipilih sebagai usaha untuk berwirausaha karena memiliki prospek yang baik, karena selain hasil nelayan melimpah, juga mengandung protein yang tinggi. Mengingat manfaat dan kandungan gizi yang bagus maka diversifikasi ikan teri diperlukan agar produk lebih bisa diterima oleh pasar. Tujuan kegiatan ini adalah menginspirasi mitra pengabdian masyarakat tentang sebuah ide dan semangat berwirausaha dengan sumber bahan baku yang mudah didapatkan dan ada disekitar mereka sehingga dapat menambah penghasilan rumah tangga. Program ini dilakukan melalui dua tahap, yaitu pengolahan ikan teri menjadi kripik siap saji menyehatkan dan transfer teknologi pengemasan. Melalui kegiatan pengabdian kepada masyarakat ini maka dilakukan pelatihan dan pengembangan teknologi pengolahan ikan teri menjadi produk komoditas ekonomi berupa kripik, yang dapat memberikan alternatif usaha perekonomian baru di masyarakat. Dampak positif dari kegiatan ini adalah meningkatnya keterampilan dan pengetahuan mitra terkait pembuatan olahan produksi dari ikan teri, termasuk juga mengenai teknik pengemasan terlihat dari peningkatan skills dalam mengemas produk. Terjadi peningkatan kemampuan mitra dalam berwirausaha dalam memproduksi dan menjual produk.
\end{abstract}

Kata Kunci: Kripik, Kampung Nelayan, Kota Palopo, Wirausaha, Ikan Teri

\section{PENDAHULUAN}

Ikan teri (Stolephorus commersonnii) merupakan salah satu hasil tangkapan perikanan pelagis kecil di Teluk Bone yang memiliki nilai ekologis sebagai rantai makanan di perairan. Ikan teri digemari masyarakat Indonesia karena kandungan gizinya. Ikan teri dipasarkan dalam bentuk segar atau dalam bentuk olahan sebagai ikan asin. Harga ikan teri di PPN Kota Palopo mencapai Rp. 10.000 per kg. Penangkapan ikan teri dilakukan pada malam hari dengan alat tangkap bagan apung pada mesh size $1 \mathrm{~mm}$ (PPN 2016).

Usaha pengolahan ikan teri baik dalam bentuk ikan asin maupun turunannya di Kota Palopo memiliki beberapa permasalahan yang dialami oleh pengolah, salah satunya yaitu kegiatan pemasaran yang seringkali tidak mencapai kondisi yang efisien. Menurut Ismail et al. (2008) pemasaran merupakan kegiatan yang penting dalam menjalankan usaha perikanan, karena pemasaran merupakan tindakan ekonomi yang berpengaruh terhadap naik turunnya pendapatan, produksi akan sia-sia bila harga rendah, maka pemasaran harus baik dan efisien. Hasil-hasil

To Maega, 2(1), Februari $2019 \mid 25$ 
perikanan supply tidak sama dengan demand, hal ini mempengaruhi terjadinya fluktuasi harga. Hal ini perlu mendapat perhatian, karena dengan sistem pemasaran yang cepat dan tepat maka pengolah akan memperoleh pendapatan yang cepat dan jelas. Oleh karena itu, untuk meningkatkan harga jual dan keuntungan ikan teri maka diperlukan pengolahan melalui kewirausaha kripik ikan teri (Sapereng et al. 2017).

Produk berupa kripik sehat dipilih sebagai usaha untuk berwirausaha karena memiliki prospek yang baik. Selain itu kripik ikan teri bisa dijadikan peluang usaha yang menguntungkan karena bisa membantu peningkatan gizi. Kandungan yang ada dalam ikan teri memiliki banyak kegunaan untuk dijadikan olahan masakan dengan berbagai cara, rasa, serta cara penyajian maupun makanan yang beranekaragam. Tidak boleh dilupakan juga yang harus diperhatikan adalah faktor kualitas, karena preferensi konsumen terhadap atribut produk terletak pada komponen kualitas (Herlambang et al. 2018; Sapareng et al, 2019). Kesadaran akan pentingnya kewirausahaan harus ditingkatkan dan didukung mengingat hal ini akan sangat membantu perekonomian keluarga (Rohmani et al. 2018), sehingga diharapkan mampu meningkatkan kesejahteraan penghasilan keluarga serta juga mampu berinovasi dalam memperingan pengeluaran keluarga tanpa mengurangi kebutuhan gizi keluarga karena selain nikmat juga menyehatkan.

Warga di Kelurahan PonjalaE, Kecamatan Wara Timur Kota Palopo yang memiliki pekerjaan utama sebagai nelayan. Sampai saat ini umumnya pemanfaatan ikan teri hanya dikonsumsi dalam bentuk segar ataupun ikan teri, hal ini dikarenakan kurangnya pengetahuan dan keterampilan tentang pengolahan makanan kecil berbahan dasar ikan teri (Gambar 1). Salah satu upaya untuk memberikan nilai tambah dari ikan teri adalah dengan mengolah ikan teri menjadi olahan makanan (kripik) yang lebih bervariatif. Untuk mencapai tujuan tersebut tim melakukan pembinaan terhadap mitra melalui pendampingan dalam proses produksi. Meningkatnya kreativitas makanan berbahan dasar ikan teri diharapkan dapat membuka peluang usaha baru bagi masyarakat. Tujuan kegiatan ini adalah untuk menginspirasi mitra pengabdian masyarakat tentang ide dan semangat berwirausaha dengan sumber bahan baku yang mudah didapatkan dan ada disekitar mereka sehingga dapat menambah penghasilan rumah tangga.
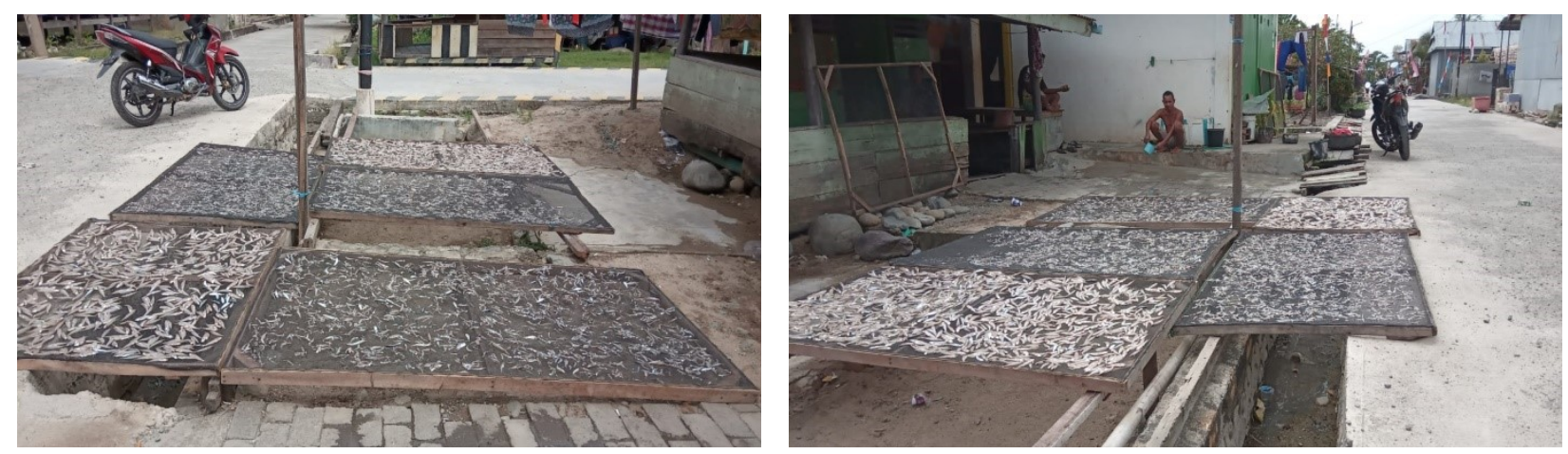

Gambar 1. Ikan teri yang dikeringkan 


\section{METODE PELAKSANAAN KEGIATAN}

\section{Waktu dan Tempat}

Kegiatan dilaksanakan selama 2 bulan pada bulan Agustus - September 2018. Lokasi kegiatan pengabdian di Kampung Nelayan Kelurahan PonjalaE Kecamatan Wara Timur Kota Palopo.

\section{Metode Pelaksanaan}

Metode yang digunakan dalam kegiatan pengabdian masyarakat ini adalah metode ceramah, praktik, dan diskusi. Metode ceramah digunakan untuk menjelaskan materi tentang pengolahan kripik ikan teri. Metode praktik digunakan untuk praktik membuat olahan produk berbasis ikan teri, mulai dari pembersihan ikan teri sampai dengan pengolahan dan pengemasan. Aplikasi penggunaan mesin dan teknik pengemasan untuk meningkatkan mutu dan harga jual dengan packing yang berkualitas. Metode diskusi dilakukan setelah kegiatan pengabdian selesai untuk mengetahui respons peserta. Evaluasi peningkatan pengetahuan dan keterampilan dari mitra dilakukan melalui pre-test dan post-test. Monitoring dan evaluasi dilakukan pada saat program berlangsung.

\section{HASIL DAN PEMBAHASAN}

\section{Kegiatan Sosialisasi}

Sosialisasi kegiatan dilakukan bertempat di kediaman salah satu mitra pengabdian masyarakat di Kampung Nelayan Kelurahan PonjalaE yang dihadiri sebanyak 11 orang. Kota Palopo adalah suatu wilayah potensial penghasil ikan laut termasuk ikan teri karena daerahnya di pinggir laut dan berada di teluk Bone. Umumnya nelayan yang mendapatkan ikan teri dijemur di depan rumahnya atau pinggir jalang/lorong, kemudian dijual langsung ke pasar dan sebagian dikonsumsi. Hal ini dikarenakan kurangnya pengetahuan dan keterampilan tentang pengolahan makanan kecil (cemilan) berbahan dasar ikan teri. Salah satu upaya untuk memberikan nilai tambah adalah mengelolah ikan teri menjadi olahan makanan yang lebih bervariatif berupa kripik cemilan yang kaya protein. Meningkatnya kreativitas makanan berbahan dasar ikan teri diharapkan dapat membuka peluang usaha baru, sehingga diperlukan terobosan baru untuk membuat produk berbahan ikan teri yang sehat dan kaya protein tinggi, yang diharapkan mempunyai prospek yang bagus dan cemerlang, dan sangat diperlukan transfer teknologi untuk meningkatkan kualitas, nilai jual produk, serta strategi pemasarannya.

\section{Kegiatan Pemberdayaan Masyarakat}

Pemberdayaan masyarakat dilakukan melalui kegiatan pelatihan dan pendampingan dalam pembuatan produk olahan ikan teri dalam bentuk kripik, beserta cara pengemasan produknya. Adanya transfer teknologi diharapkan mampu meningkatkan kapasitas produksi dan nilai ekonomi produk. Pada kegiatan ini dilakukan pembinaan terhadap mitra melalui pendampingan dalam proses produksi kripik ikan teri. Mitra memiliki upaya pengembangan makanan sehat sebagai upaya peningkatan asupan protein bagi anak-anak, pencegahan penyakit serta peningkatan komoditas ekonomi masyarakat, dan mengingat bahaya mengkonsumsi kripik yang

To Maega, 2(1), Februari 2019|27 


\section{TO MAEGA | Jurnal Pengabdian Masyarakat}

P-ISSN: 2622-6332 \& E-ISSN: 2622-6340

TO MAEGA Volume 2 Nomor 1, Februari 2019, hlm : 25 - 29

banyak mengandung micin tidak baik bagi kesehatan terutama anak-anak maka kegiatan pengabdian masyarakat ini akan dilakukan secara terpadu untuk memberikan solusi.

\section{Transfer teknologi dalam pembuatan kripik ikan teri dalam kemasan}

Kegiatan ini berupa ceramah dan diskusi tentang produk olahan ikan teri dalam bentuk jajanan sehat yang kaya protein berupa kripik yang dapat diproduksi dalam skala rumah tangga. Kegiatan ini adalah transfer teknologi pembuatan kripik ikan teri yang inovatif dalam kemasan. Disebut kripik ikan teri inovatif karena bahan yang digunakan berbahan dasar formulasi produk kripik dari ikan teri segar yang selama ini tidak maksimal pemanfaatannya tapi ternyata bermanfaat bagi kesehatan yang kaya protein.

\section{Proses produksi dan packaging kripik ikan teri dalam kemasan}

Pelatihan diikuti praktik pembuatan kripik ikan teri dalam kemasan oleh kelompok mitra. Praktik secara mandiri oleh kelompok mitra didampingi oleh tim pelaksana dan dilakukan untuk meningkatkan keterampilan praktis para anggota mitra. Pada kegiatan praktik produksi kripik, dimulai dengan proses pembuatan kripik dengan bahan dasar ikan teri, yang dibuat dengan cara dicampur dengan tepung kanji serta ditambahkan bumbu lainnya sebagai pelengkap dan perasa. Proses pembuatan kripik ikan teri terlihat pada Gambar 2.

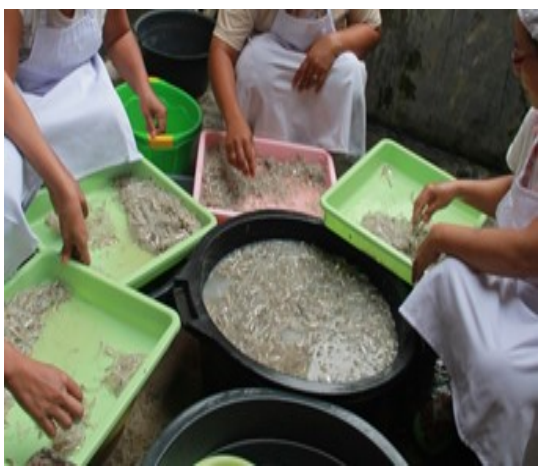

a

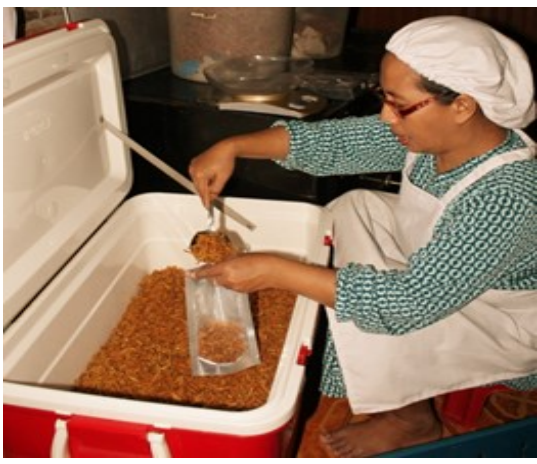

d

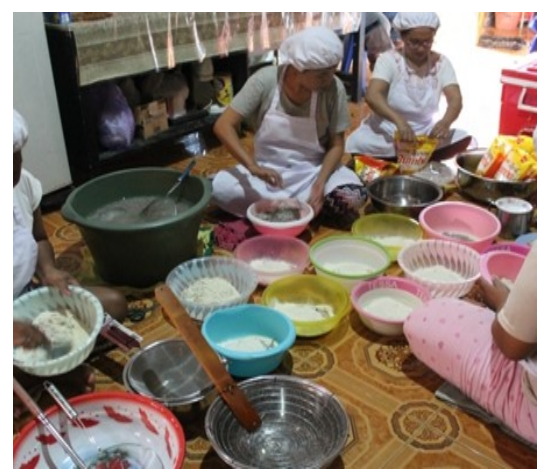

b

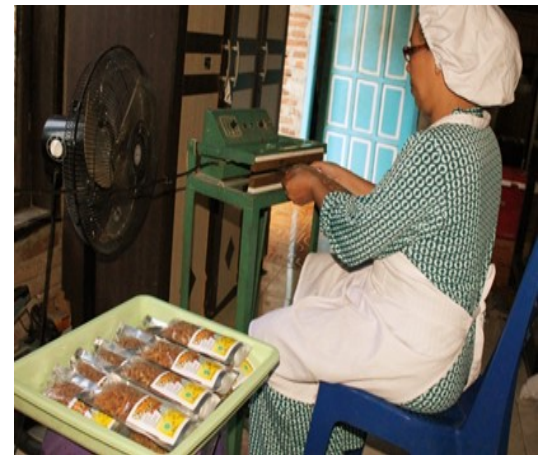

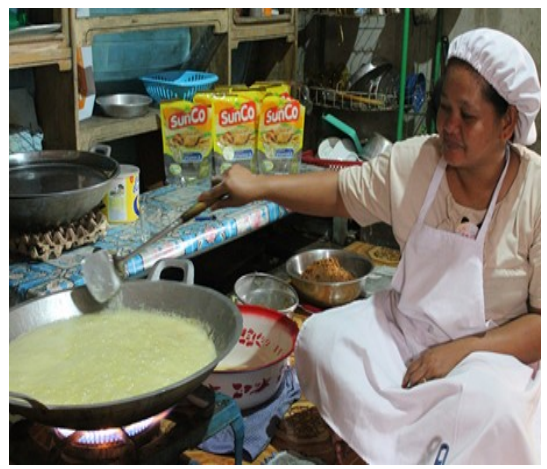

c

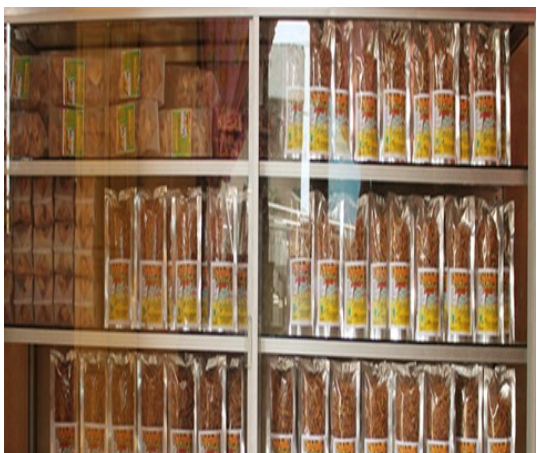

f

Gambar 2. Proses pembuatan kripik ikan teri a). Perendaman dan pembersihan ikan teri; b). Pencampuran ikan teri dengan tepung; c). Penggorengan ikan teri basah; d). Pengemasan kripik ikan teri; e). Penimbangan kripik ikan teri; f). Kripik ikan teri gurih siap dipasarkan 


\section{TO MAEGA | Jurnal Pengabdian Masyarakat}

P-ISSN: 2622-6332 \& E-ISSN: 2622-6340

TO MAEGA Volume 2 Nomor 1, Februari 2019, hlm : 25 - 29

\section{KESIMPULAN}

Kegiatan pengabdian untuk pemberdayaan masyarakat dalam membuat produk olahan kripik dari ikan teri membawa dampak positif. Selain untuk meningkatkan nilai ekonomi dari ikan teri juga memberi manfaat bagi mitra, yaitu meningkatnya keterampilan dan pengetahuan mitra terkait pembuatan olahan produksi dari ikan teri, termasuk juga mengenai teknik pengemasan. Hasil dari kegiatan ini terlihat ada peningkatan kemampuan mitra dalam berwirausaha dalam memproduksi dan menjual produk. Kedepannya produk bisa didaftarkan ke dinkes setempat untuk bisa mendapatkan sertifikat PIRT.

\section{UCAPAN TERIMAKASIH}

Ucapan terima kasih kepada Universitas Andi Djemma Palopo, yang telah mendanai kegiatan ini sehingga kegiatan ini terlaksana dengan baik dan lancar.

\section{DAFTAR PUSTAKA}

Herlambang A, Asmawati E, Haryono Y. 2018. Implementasi Cara Produksi Pangan yang Baik Untuk Industri Rumah Tangga Kerupuk di Sidoarjo. Agrokreatif Jurnal Ilmiah Pengabdian kepada Masyarakat. 4(1): 31-37.

https://doi.org/10.29244/agrokreatif.4.1.3137

Ismail G, Supardi S, dan Wahyuningsih S. 2008. Analysis efficiency marketing system of fresh laying fish (decapterus russeli) on pelabuhan fish auction place in Tegal City. Jurnal Mediagro. IV (2): 39-50.

[PPNP] Pelabuhan Perikanan Nusantara Kota Palopo. 2016. Statistik Perikanan Pelabuhan Perikanan Nusantara Kota Palopo. Palopo

Rohmani S, Yugatama A, Prihapsara F. 2018. Inovasi Minuman Sehat Berbahan Kedelai dalam Upaya Pemberdayaan Masyarakat melalui Wirausaha di Kabupaten Sukoharjo. Agro Kreatif Jurnal Ilmiah Pengabdian kepada Masyarakat. 4(2): 68-74.

https://doi.org/10.29244/agrokreatif.4.1.68-74

Sapareng S, Idris MY, Intisari, Yasin SM, Rosnina, 2019. Kualitas Bibit Durian Unggul Lokal Palopo. Caradde, Jurnal Pengabdian Kepada Masyarakat. 1(2): 76-83.

Sapareng S, Akmal, Halid I, 2017. Sistem Budidaya Lorong (Alley Cropping) pada Pertanaman Kakao dengan Tanaman Nilam di Kecamatan Malangke Kabupaten Luwu Utara. Jurnal Balireso. 2(1): 28-36. 